\title{
CORPORATE GOVERNANCE, PROFITABILITY, AND FIRM VALUE STUDY ON THE INDONESIAN ISLAMIC INDEX
}

\author{
Sutrisno, Sutrisno ${ }^{a}$

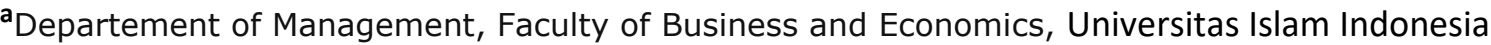 \\ Email: sutrisno@uii.ac.id
}

\begin{abstract}
ARTICLE HISTORY
ABSTRACT

Received:

16 November 2020

Revised:

4 December 2020

Accepted:

7 December 2020

Online available:

11 December 2020

\section{Keywords:}

Board of Directors,

Board of

Commissioner, Institution Ownership, Managerial Ownership, Firm Value.

The purpose of this study is to examine the effect of corporate governance mechanisms and profitability on firm value. The corporate governance mechanism consists of a board of directors, a board of commissioners, managerial ownership, and institutional ownership. Firm value is measured by Tobin's Q, while profitability is measured by return on assets. The population in this study were companies listed on the Indonesian Sharia Stock Index with a total sample of 103 companies taken by purposive sampling method. The observation period is for five years from 2015 to 2019. To test the hypothesis, the author applies panel data regression analysis. In selecting the panel data model, after being tested, the best model is the fixed effect model. The results of the research based on the fixed effects model show that the board of commissioners has a significant but negative effect on firm value, while the board of directors and profitability and ownership of institutions have a significant and positive effect on firm value, but managerial ownership has no significant effect on firm value.
\end{abstract}

*Correspondence:

Name: Sutrisno

E-mail:

sutrisno@uii.ac.id

\section{INTRODUCTION}

Corporate governance or often referred to as good corporate governance (GCG) is very much needed by banking institutions to maintain the trust of the people who save their funds in banks. In accordance with the principles of GCG, companies must disclose company data and information in a transparent, accountable, responsible, independent, and fair manner. With GCG, the public and investors can find out the real condition of the company. With good governance, people trust the company, and these trust investors will buy their shares so that they can increase the value of the company. As found by Ararat, Black, \& Yurtoglu(2017) and Al-ahdal, Alsamhi, Tabash, \& Farhan(2020) that the implementation of GCG has a positive effect on firm value. The GCG mechanism can be through independent commissioners, board of directors, quality audit commissions, or through ownership structures such as institutional ownership, managerial ownership, and foreign ownership. Some researchers also found that corporate governance mechanisms have an effect on firm value (Ali, 2018; Ammann, Oesch, \& Schmid, 2011; Ararat et al., 2017).

The aim of the company is to increase the value of the company, namely to improve the welfare of shareholders. Firm value is the investor's perception of the company's success 
rate which is often associated with the stock price. The high share price will increase investors' confidence in the company's current performance and its prospects for the future. Fundamentally, firm value will be influenced by the company's financial performance (profitability), because with high profitability the company is expected to be able to pay dividends, which will increase the share price (Fajaria, 2018). Therefore, the task of management is to continuously improve company performance through profitability.

The implementation of good corporate governance in the company will provide direction for managers and employees to work better, so that it is expected to be able to improve the performance or profitability of the company (Yameen, Farhan, \& Tabash, 2019). Good GCG implementation will also increase investor confidence, so that company shares will be preferred by investors, and with the implementation of GCG, in addition to being able to increase productivity, it will also increase firm value (Li \& Zaiats, 2018; Kim, 2012; Ciftci, Tatoglu, Wood, Demirbag, \& Zaim, 2019).

The board of directors is a company organ appointed by the owner to manage the company and one of the most important mechanisms in corporate governance and the protection of governance structures between the company and shareholders (Makhlouf, Laili, Ramli, Al-Sufy, \& Basah, 2018). This board of directors has great power in making decisions so that the size of the board of directors will affect the company's performance. The research results are still not robust, because the research results are not consistent. Salem, Metawe, Youssef, \& Mohamed (2019); Naciti, (2019) found that the board of directors had a significant positive effect on firm value, while Makhlouf et al(2018) and Yameen et al., (2019) found that the board of directors had a negative effect on firm value. This is presumably because there are too many boards of directors, which increases the company's operating costs.

In order for the board of directors to carry out the company's activities in accordance with the owner's goals, the owner shall appoint a supervisory board which is known as the board of commissioners. The board of commissioners must be able to ensure that the duties of the board of directors are in accordance with the direction of the shareholders through the general meeting of shareholders (Kao, Hodgkinson, \& Jaafar., 2019). Good supervision from the board of commissioners will be able to control the board of directors to work effectively and efficiently so that it can increase firm value (Al-ahdal et al., 2020). Yacob, Jambi, Rahayu, \& Jakarta(2019) found a positive and significant influence between the board of commissioners and firm value, while Susanti \& Nidar(2016) found a negative effect of the number of commissioners on firm value

Managerial ownership is a mechanism in corporate governance where managers are involved in share ownership. Providing opportunities for managers to be involved in share ownership aims to equalize the interests of managers with those of shareholders. This involvement will encourage managers to act prudently because managers will share the consequences for the decisions they make. In addition, managers will be motivated to improve their performance in managing the company. This managerial ownership will be measured by the proportion of shares owned by managers, commissioners and directors of the company at the end of the year which is then expressed as a percentage (Robin \& Amran, 2016).(Ali, 2018) dan (Robin \& Amran, 2016) found a significant and positive influence between managerial ownership and company performance.

Institutional ownership is also one of the GCG mechanisms because it is often an indicator of the issuer's performance. Issuers that perform well are highly sought after by institutional investors. Therefore, ownership of this institution is often followed by individual investors in investing. In addition, institutional ownership can also help companies oversee 
company management and can ensure that company management can manage company assets properly so as to create high profitability (Abdullah, Ali, \& Haron(2017). Empirically, institutional ownership affects firm value(Abbasi, Kalantari, \& Abbasi, 2012; Navissi \& Naiker, 2006).

Profitability is the company's ability to generate profits with the capital it owns. Profitability shows the company's financial performance which is used as an indicator of the company's good and bad. The amount of profitability shows that the company's management is working effectively and efficiently (Tui, Nurnajamuddin, Sufri, \& Nirwana(2017). Investors are genuinely concerned about profitability because with high profitability the company will be able to distribute dividends, so that its stocks are favored by investors. Research result of Fajaria(2018) found a positive and significant influence between profitability as measured by return on assets (ROA) and firm value measured by Tobin's Q. Irawan \& Devie(2017); Kumalasari \& Pratikto(2018). dan Tui, Nurnajamuddin, Sufri, \& Nirwana(2017) also found the effect of profitability on firm value, however Robin \& Amran(2016)found that profitability did not affect firm value.

The object of this research is the Islamic capital market, namely Emiten, whose shares are listed on the Indonesian Islamic Stock Index (IISI). The Islamic capital market has its own appeal for Muslim investors who avoid shares in companies that operate not in accordance with Islamic sharia (Maiyaki, 2013). This object is interesting because the development of investors is very fast. Shares listed on IISI are also growing very rapidly, to date more than 350 issuers are members of IISI (Hamimi \& Ginting, 2019), so it is interesting for the author to do research on IISI.

There have been quite a number of previous researchers conducting research on the topic of corporate governance, profitability and firm value. What distinguishes this study from previous research is that the hypothesis is tested using panel data analysis, while most researchers use multiple regression analysis. Panel data analysis is used because the data of this study consist of time series data for 5 years and cross section data consisting of 103 companies. The combined data is panel data so it should be analyzed using panel data regression (Widarjono, Anto, \& Fakhrunnas, 2020).

\section{LITERATURE REVIEW}

\section{Board of Director and Firm Value}

Makhlouf et al., (2018)describes the board of directors as having a major role in the corporate governance structure that determines the success of a company. The existence of an effective board of directors is particularly important in supporting the functioning of the company in improving company performance. The more the board of directors, the considerations in making decisions are more mature and planned, because each director has expertise and skills in his field. Therefore, the more the board of directors the more trusted it will be to make the company improve its performance. By improving the company's performance, it will be able to attract investors to buy more company shares, thereby increasing the stock price, thereby increasing the company's value. Several research results indicate that the size of the board of directors can have a positive or negative impact on firm value. Salem et al(2019) found that in the USA and Egypt, board size has a positive effect on firm value. Ciftci et al(2019) also found a positive effect of the board of directors on firm value.

$\mathrm{H}_{1}$ : The board of directors has a positive effect on firm value 


\section{Borad of Commissioner and Firm Value}

The Board of Commissioner (BOC) represents the internal mechanism of GCG to control and oversee management behavior in managing the company so that it can align the interests of shareholders and company managers (Jensen \& Meckling, 1976). Chabachib, Hersugondo, Ardiana, \& Pamungkas(2019) said that board of commissioner is the core of GCG which is tasked with ensuring company strategy and supervising managers in managing the company, so that BOC has a very strong influence on firm value. In addition, Yacob, Jambi, Rahayu, \& Jakarta(2019)andCiftci et al., (2019) also found similar results that the board of commissioners had a positive influence on firm value. Based on the description above, the hypothesis in this study is:

\section{$\mathrm{H}_{2}$ : The board of commissioner has a positive effect on Firm Value}

\section{Profitability and Firm Value}

Profitability is one information that can be used as a signal to investors that the company has good financial performance (Ararat et al., 2017). With high profitability, it is expected that the company will distribute high dividends, so that profitability will be able to encourage investors to purchase shares. The more investors buy company shares, the demand for shares will increase, which in turn will increase the stock price. Fajaria(2018) found a positive and significant effect between profitability as measured by return on assets (ROA) and firm value measured by Tobin's Q. Tui, Nurnajamuddin, Sufri, \& Nirwana(2017) also found the effect of profitability on firm value.

\section{$\mathrm{H}_{3}$ : Profitability has a positive effect on firm value}

\section{Institutional ownership and firm value}

There is a positive relationship between institutional ownership and firm value (Abbasi, Kalantari, \& Abbasi, 2012; Navissi \& Naiker, 2006). When institutions are classified into domestic and foreign, however, it turns out that firm value increases with higher ownership by domestic institutions, but deteriorates with higher ownership by foreign institutions. These findings have important implications regarding the relationship between institutional ownership and corporate governance. On the one hand, domestic institutional investors seem to be effective in providing monitoring activities, thereby reducing agency costs for free cash flow which tend to increase when there is a large excess of cash under the control of managers (Jo \& Harjoto, 2011). In connection with the description above, a hypothesis can be put forward:

\section{$\mathrm{H}_{4}$ : Institutional ownership has a positive effect on firm value}

\section{Managerial ownership and Firm Value}

In agency theory, it is explained that managers and shareholders are two parties who have different interests, and that difference causes agency conflicts (Jensen \& Meckling, 1976). This conflict can affect each party in maximizing their welfare. Shareholders are worried about the control over the company that is held by managers, because there is a possibility that managers will make decisions that are detrimental to shareholders or take actions that take advantage of company resources for their own welfare. To overcome this, shareholders supervise managers (Jensen \& Meckling, 1976). To overcome this, company owners compensate managers in the form of share ownership so that thoughts are in line and firm values are always strived to be optimized for the welfare of shareholders. What 
shareholders need to do is form an optimal managerial ownership composition that will increase firm value. According to the findings of Robin \& Amran(2016), the amount of managerial ownership has a positive effect on firm value. Ali(2018) and Putranto(2018) also found a positive influence between managerial ownership and firm value.

$H_{5}$ : Managerial Ownership has a positive effect on firm value

\section{RESEARCH METHOD}

\section{Population and Sample}

The population in this study was more than 350 companies listed on the Indonesian Sharia Stock Index. The sample to be taken is 103 companies taken by purposive sampling with the criteria of companies that publish complete periodic annual reports during the observation period. The data required is an annual financial report and an annual GCG report for 5 years (2015-2019).

\section{Reseach Variables}

This study consists of one dependent variable, namely firm value, five independent variables consisting of the board of commissioners, board of directors, profitability, institution ownership and managerial ownership, and one controlling variable for firm size. The following table is the research variable and how to measure it:

Table 1

Varible and Measurement

\begin{tabular}{rll}
\hline No & \multicolumn{1}{c}{ Variable } & \multicolumn{1}{c}{ Measurement } \\
\hline 1 & Firm Value (TQ) & (Market of Common stock+Total Dbet)/Total Assets \\
2 & Board of Commissioner (BOC) & Sum of Board of Commissioner \\
3 & Board of Director (BOD) & $\begin{array}{l}\text { Sum of Board of Director } \\
\text { Number of shares owned by the Institution/Number of } \\
\end{array}$ \\
4 & Instituional Ownership (IOWN) & $\begin{array}{l}\text { shares in the market } \\
\text { Number of shares owned by Manager/Number of }\end{array}$ \\
5 & Managerial Ownership (MOWN) & shares in the market \\
6 & Profitability (ROA) & Earning After Tax/Total Assets \\
7 & Firm Size (SIZE) & Log natural Total Assets \\
\hline
\end{tabular}

Data Analysis

The available data are panel data consisting of 103 companies and a five-year observation period. Therefore, to test the hypothesis, panel data regression will be used. The research model with panel data regression is as follows:

$$
\mathrm{TQ}_{i \mathrm{t}}=\alpha+\beta_{1} \mathrm{BOC}_{i \mathrm{t}}+\beta_{2} \mathrm{BOD}_{\mathrm{it}}++\beta_{3} \mathrm{ROA}_{\mathrm{it}}+\beta_{4} \mathrm{IOWN}_{\mathrm{it}}+\beta_{5} \mathrm{MOWN}_{\mathrm{it}}+\beta_{6} \mathrm{SIZE}_{i \mathrm{t}}+\varepsilon
$$

The significance used in this study is indicated by an asterisk on the results. ${ }^{* * *}$ ) sign at $1 \%$, ${ }^{* *}$ ) sign at $5 \%$ and ${ }^{*}$ ) sign at $10 \%$. Size variable is a control variable, so the results are not discussed further. Researchers focus on BOC, BOD, IOWN, MOWn and profitability

\section{RESULT AND ANALYSIS Descriptive Statistics}

The description of the research data in the form of minimum, maximum, mean and standard deviation values processed by e-Views 10 , is as follows: 
Table2

Descriptive Statistics

\begin{tabular}{llrrrr}
\hline & N & Minimum & Maximum & Mean & Std. Deviation \\
\hline TQ & 515 & 0.03 & 23.29 & 1.6226 & 2.0112 \\
BOC & 515 & 1.00 & 12.00 & 4.5087 & 1.88312 \\
BOD & 515 & 1.00 & 16.00 & 5.1961 & 2.24873 \\
ROA & 514 & -0.60 & 2.00 & 0.0559 & 0.13125 \\
IOWN & 515 & 0.00 & 90.76 & 1.0045 & 5.33823 \\
MOWN & 515 & 0.00 & 5.50 & 0.0528 & 0.26809 \\
SIZE & 515 & 23.39 & 33.49 & 27.7866 & 1.68083 \\
\hline
\end{tabular}

Source: Data processed

The table above shows that the firm value (Tobin's Q) has a minimum value of 0.03 and a maximum value of 23.29 with an average value of 1.62 , meaning that the sample companies have a firm value above their book value which is indicated by their average value. Meanwhile, the board of commissioners (BOC) has a minimum value of 1 , meaning that there are companies that only have one board of commissioners with a maximum of 12 people. However, the average number of commissioners in the sample companies is 4.6 people. Meanwhile, the minimum number of boards of directors is 1 with a maximum of 16 people, with an average number of directors of 5.2.

Profitability as measured by ROA shows a minimum value of $-0.60 \%$, meaning that there are sample companies that suffer losses with a maximum ROA of $2.00 \%$ with an average of $0.06 \%$, meaning that the ROA of the sample companies is relatively small. Institutional ownership has a minimum value of 0 with a maximum value of $90.76 \%$ with an average of $1.01 \%$, meaning that institutional ownership is still extremely low in the sample companies. Meanwhile, managerial ownership has a minimum value of $0 \%$ and a maximum value of $5.5 \%$ with an average value of $0.05 \%$, which means that managerial ownership in the sample companies is very small.

\section{Correlation Matrix}

The correlation matrix is an econometric tool that tests the tendency of the relationship between variables. This shows how significant the relationship between the research variables is. It also provides an indication of the absence and presence of multicollinearity. If an independent variable in a model has a variation factor value of more than or equal to 10 , this indicates multicollinearity in the model.

Table 3

Matrix Correlations

\begin{tabular}{llrrrrr}
\hline & & \multicolumn{1}{c}{ BOC } & \multicolumn{1}{c}{ BOD } & \multicolumn{1}{c}{ ROA } & IOWN & MOWN \\
\hline BOC & Pearson Correlation & 1 & $.539^{* *}$ & 0.075 & -0.051 & -0.073 \\
& Sig. (2-tailed) & & 0.000 & 0.089 & 0.250 & 0.100 \\
& N & 515 & 515 & 514 & 515 & 515 \\
\hline BOD & Pearson Correlation & $.539^{* *}$ & 1 & $.114^{* *}$ & -0.043 & $-.089^{*}$ \\
& Sig. (2-tailed) & 0.000 & & 0.010 & 0.327 & 0.044 \\
& N & 515 & 515 & 514 & 515 & 515 \\
\hline
\end{tabular}


Jurnal Ekonomi dan Bisnis Islam, Vol. 6, No. 2, July - December 2020

\begin{tabular}{llrrrrr} 
ROA & Pearson Correlation & 0.075 & $.114^{* *}$ & 1 & $.159^{* *}$ & 0.031 \\
& Sig. (2-tailed) & 0.089 & 0.010 & & 0.000 & 0.478 \\
& N & 514 & 514 & 514 & 514 & 514 \\
\hline IOWN & Pearson Correlation & -0.051 & -0.043 & $.159^{* *}$ & 1 & -0.022 \\
& Sig. (2-tailed) & 0.250 & 0.327 & 0.000 & & 0.620 \\
& N & 515 & 515 & 514 & 515 & 515 \\
\hline MOWN & Pearson Correlation & -0.073 & $-.089^{*}$ & 0.031 & -0.022 & 1 \\
& Sig. (2-tailed) & 0.100 & 0.044 & 0.478 & 0.620 & \\
& N & 515 & 515 & 514 & 515 & 515 \\
\hline
\end{tabular}

**. Correlation is significant at the 0.01 level (2-tailed).

*. Correlation is significant at the 0.05 level (2-tailed).

Table 3 shows the correlation between the independent variables. Overall, the correlation between variables is less than 0.7 . The maximum correlation is -0.43 , which is found between the independent variable BOD and the independent variable IOWN. While the remaining correlation between the independent variables is less than 0.55 . Based on the correlation between the independent variables, there appears to be concern about possible multicollinearity problems in our model.

\section{Hypothesis Testing Result}

Hypothesis testing tool in this study is panel data regression analysis. In panel data analysis, there are three models that must be chosen the best, namely the common effect, fixed effect, or random effect model. Following are the results of calculations using the eViews of each model.

Table 4

Determinant of Firm Value (Tobin's Q)

\begin{tabular}{lccc}
\hline \multicolumn{1}{c}{ Variable } & Pooled & Fixed & Random \\
\hline C & 0.9374 & 6.7040 & 2.4610 \\
& 0.5437 & 2.2394 & 2.8047 \\
BOC & -0.1251 & -0.1319 & -0.1097 \\
& $-2.2221^{* *}$ & $-3.1687^{* * *}$ & $-2.8046^{* * *}$ \\
BOD & 0.2274 & 0.0891 & 0.0272 \\
& $4.7876^{* * *}$ & $2.0785^{* *}$ & 0.6913 \\
IOWN & -0.0179 & 0.0115 & 0.0095 \\
& -1.1365 & $1.8628^{*}$ & 1.5506 \\
MOWN & -0.2013 & -0.1438 & -0.1439 \\
& -0.6493 & -1.0907 & -1.1034 \\
ROA & 4.62390 & 3.1736 & 0.0537 \\
& $7.1431^{* * *}$ & $5.6802^{* *}$ & $0.2124 *$ \\
SIZE & -0.00558 & -0.1804 & -0.04149 \\
& -0.0848 & $-1.7294^{*}$ & $-0.5496 *$ \\
R-Square & 0.1469 & 0.9374 & 0.0210 \\
$\mathrm{~N}$ & 535 & 535 & 535 \\
F-test & 0.0000 & 0.0000 & 0.0935 \\
Chi test & & & 0.0000 \\
\hline
\end{tabular}

Note: $* * *, * *, *$ denote significant $1 \%, 5 \%$, and $10 \%$ respectively

$\mathrm{N}$ is the number of observations 
To choose which model is the best among the three models, it takes the following steps. The first step is to choose between the common effect model and the fixed effect, using the Chow test, and the results of the fixed effect model are better than the common effect. The second step is to choose between the common effect model and the random effect with the Lagrange Multiplier test, which results in a better random effect model. Then the third step is to choose the best model between the fixed effect and the random effect using the Hausman test. The Hausman test results show that the fixed effect model is better than the random effect model. Thus, what will be used for further discussion is the results of hypothesis testing based on the fixed effect model.

Based on table 4 above, it can be concluded that the board of commissioners (BOC) has a significant but negative effect on firm value, while the board of directors (BOD) has no effect on firm value. Managerial ownership (MOWN) has no significant effect while institutional ownership (IOWN) has a positive effect on firm value. Meanwhile, profitability has a positive effect on firm value, as well as firm size.

\section{Analysis Research}

The results of the hypothesis test state that the board of commissioners (BOC) has a significant but negative effect on firm value. This means that more members of the board of commissioners actually reduce the value of the company. Supposedly, BOC as an internal GCG mechanism is needed to guarantee company strategy and supervise managers in managing the company. However, the negative influence indicates that the large number of BOCs can reduce the effectiveness of supervision of the board of directors to have a better quality in decision making so that it can affect investors and ultimately will have an effect on firm value. This result is in line with the research of Susanti \& Nidar (2016), andRobin \& Amran(2016) which found that the board of commissioners has no effect on firm value, it can even have a negative effect (Han \& Suk, 1998). They stated that members of the board of commissioners must be professional and have the ability and integrity to carry out their functions properly in ensuring and paying attention to the interests of the office stakeholders. Due to the high number of boards of commissioners, decision making is less effective, which will reduce firm value. Susanti \& Nidar(2016) say that the size of the board of commissioners is not the main determinant of the effectiveness of supervision of company management, because the board of commissioners is the core of corporate governance, which is assigned to guarantee company strategy, supervise managers in managing the company.

The board of directors has a significant and positive effect, meaning that the more members of the board of directors are trusted by investors, thus increasing the value of the company. This can be interpreted that BOD as an organ that has full duty and responsibility for the management of the company, plays an important role as a function of corporate decision making. In decision making, the more parties involved, the better the quality of the decisions, so that they are able to produce effective and efficient policies. The board of directors is able to overcome problems both in free-riding problems, coordination and schedule suitability issues for board members, as well as the time needed to make more agreements (Titova, 2016). Therefore, the large amount of BOD can be highly effective in making decisions, so that it will affect the value of the company. This result is in accordance with the research of Yacob et al(2019), Salem et al(2019) and Kao, Hodgkinson, \& Jaafar(2019) which state that the role of directors is very necessary in carrying out the interests and goals of the company, so that the large number of directors will provide a form of supervision for 
better company performance, good company performance is able to increase stock prices and firm value also increases.

The profitability in this study is proven to have a positive and significant effect on firm value, meaning that the higher the profitability, the higher the firm value. These results indicate that profitability can be used as an indicator of the effectiveness of company management so that it will influence investors' policies in investing (Tui et al., 2017). Profitability is a signal to investors that the company has good financial performance, which encourages investors to buy shares of issuers that provide high profitability information (Fajaria, 2018). This result is in line with the research of Tui et al(2017); Kumalasari \& Pratikto(2018) which states that information on company profitability has a significant and positive effect on firm value. This can influence investors in making investment decisions, because the company's profit (profitability) is expected by investors to be distributed as dividends. Irawan \& Devie(2017) also found that high profitability increases firm value.

Institutional ownership has a significant and positive effect on firm value, meaning that the greater the portion of institutional ownership of a company will encourage investors to follow it. Investors believe that ownership of shares by financial institutions is a positive signal so that it is expected to increase firm value(Abbasi et al., 2012). This implies that investors consider institutional ownership as an indicator of the issuer's merits. It is expected that institutional ownership can be an indicator that the company is performing well so that it can influence investors to buy its shares. This result is in line with the research findings of Abdullah, Ali, \& Haron(2017) which found that institutional ownership has a significant and positive effect on firm value. Likewise, Vintilă \& Gherghina (2015) found institutional ownership has a positive effect on firm value.

Managerial ownership does not have a significant effect on firm value, which means that the amount of managerial ownership is not able to increase the value of the company. Whereas according to Jensen \& Meckling(1976) the greater the share ownership by management, the stronger the tendency of management to optimize the use of resources, so as to increase the company's value. Management is the most aware of the internal conditions of the company, so it is suspected that better information causes management to prioritize its own interests more than those of investors. This result is also likely due to the very small managerial ownership in the sample companies, because the average ownership is only $1 \%$ so that it is unable to influence firm value. This result is consistent with the research of Abdullah et al(2017) which found managerial ownership has no effect on firm value. Even Han \& Suk(1998) found that managerial ownership has a negative effect on firm value. However, there are also many researchers who find a positive effect of managerial ownership on firm value, because the share owner manager will struggle to improve performance so that it will encourage the increase in firm value(Putranto, 2018; Ali, 2018; Robin \& Amran, 2016).

\section{CONCLUSION}

Based on the results of the analysis and discussion above, it can be concluded that there are three variables whose hypothesis is proven, namely the board of directors, profitability, and institutional ownership. All three have a significant and positive influence on firm value. Meanwhile, the board of commissioners has a significant effect, but the direction is negative, which is not in accordance with the hypothesis that the board of commissioners has a positive effect on firm value, while managerial ownership does not significantly affect firm value. 
The results of this study can be used by company management in increasing company value related to corporate governance and profitability. The main concern is the role of the board of commissioners which has a significant but negative effect, which indicates that there are too many boards of commissioners, so it is inefficient for the company. The board of directors and profitability need to be maintained because they greatly affect the value of the company.

It is expected that the results of this study can also be used by future researchers who are concerned with corporate governance, by analyzing all the variables that are proxies for GCG. Also, research can be done not only on Islamic stocks but on stocks as a whole.

\section{REFERENCE}

Abbasi, M., Kalantari, E., \& Abbasi, H. (2012). Impact of Corporate Governance Mechanisms on Firm Value Evidence from the Food Industry of Iran. Journal of Basic and Applied Scientific Research, 2(5), 4712-4721.

Abdullah, N. A. I. N., Ali, M. M., \& Haron, N. H. (2017). Ownership structure, firm value and growth opportunities: Malaysian evidence. Advanced Science Letters, 23(8), 73787382. https://doi.org/10.1166/asl.2017.9479

Al-ahdal, W. M., Alsamhi, M. H., Tabash, M. I., \& Farhan, N. H. S. (2020). The impact of corporate governance on financial performance of Indian and GCC listed firms: An empirical investigation. Research in International Business and Finance, 51(September 2018), 101083. https://doi.org/10.1016/j.ribaf.2019.101083

Ali, M. (2018). Impact Of Corporate Governance On Firm s Financial Performance (A Comparative Study Of Developed And Non Developed Markets). Journal of Business Management and Economic Research, 2(1), 15-30. https://doi.org/10.29226/tr1001.2018.7

Ammann, M., Oesch, D., \& Schmid, M. M. (2011). Corporate governance and firm value: International evidence. Journal of Empirical Finance, 18(1), 36-55. https://doi.org/10.1016/j.jempfin.2010.10.003

Ararat, M., Black, B. S., \& Yurtoglu, B. B. (2017). The effect of corporate governance on firm value and profitability: Time-series evidence from Turkey. Emerging Markets Review, 30(November 2014), 113-132. https://doi.org/10.1016/j.ememar.2016.10.001

Chabachib, M., Hersugondo, H., Ardiana, E., \& Pamungkas, I. D. (2019). Analysis of Company Characteristics of Firm Values: Profitability as Intervening Variables. International Journal of Financial Research, 11(1), 60. https://doi.org/10.5430/ijfr.v11n1p60

Ciftci, I., Tatoglu, E., Wood, G., Demirbag, M., \& Zaim, S. (2019). Corporate governance and firm performance in emerging markets: Evidence from Turkey. International Business Review, 28(1), 90-103. https://doi.org/10.1016/j.ibusrev.2018.08.004

Fajaria, A. Z. (2018). The Effect of Profitability, Liquidity, Leverage and Firm Growth of Firm Value with its Dividend Policy as a Moderating Variable. International Journal of Managerial Studies and Research, 6(10), 55-69. https://doi.org/10.20431/23490349.0610005

Hamimi, S., \& Ginting, Y. R. F. (2019). The Development Of Islamic Capital Markets In Indonesia. Proceeding International Seminar on Islamic Studies, 1(1), 762-767.

Han, \& Suk. (1998). The Effect of Ownership Structure on Firm Performance. Review of Financial Economics, 7(2), 143-155.

Irawan, N., \& Devie. (2017). Pengaruh Corporate Governance Terhadap Firm Value Dengan 
Financial Performance Sebagai Variabel Intervening Pada Perusahaan LQ 45 Tahun 2012-2015. Business Accounting Review, 5(1), 277-288.

Jensen, M. C., \& Meckling, W. H. (1976). Theory of the firm: Managerial behavior, agency costs and ownership structure. Journal of Financial Economics.

https://doi.org/10.1016/0304-405X(76)90026-X

Jo, H., \& Harjoto, M. A. (2011). Corporate Governance and Firm Value: The Impact of Corporate Social Responsibility. Journal of Business Ethics. https://doi.org/10.1007/s10551-011-0869-y

Kao, M. F., Hodgkinson, L., \& Jaafar, A. (2019). Ownership structure, board of directors and firm performance: evidence from Taiwan. Corporate Governance (Bingley), 19(1), 189216. https://doi.org/10.1108/CG-04-2018-0144

Kim, B.-M. (2012). Tax Avoidance, Corporate Governance, and Firm Value. 재무관리연구, 29(4), 61-92.

Kumalasari, D., \& Pratikto, H. (2018). Good Corporate Governance Affects on Corporate Value Through Return on Equity and Return on Asset of Manufacture Company. KnE Social Sciences, 3(3), 114. https://doi.org/10.18502/kss.v3i3.1878

Li, T., \& Zaiats, N. (2018). Corporate governance and firm value at dual class firms. Review of Financial Economics, 36(1). https://doi.org/10.1016/j.rfe.2017.07.001

Maiyaki, A. A. (2013). Principles of Islamic Capital Market. International Journal of Academic Research in Accounting, Finance and Management Sciences, 3(4), 278-283. https://doi.org/10.6007/IJARAFMS/v3-i4/477

Makhlouf, M. H., Laili, N. H., Ramli, N. A., Al-Sufy, F., \& Basah, M. Y. (2018). Board of directors, firm performance and the moderating role of family control in JORDAN. Academy of Accounting and Financial Studies Journal, 22(5), 1-15.

Naciti, V. (2019). Corporate governance and board of directors: The effect of a board composition on firm sustainability performance. Journal of Cleaner Production, 237, 117727. https://doi.org/10.1016/j.jclepro.2019.117727

Navissi, F., \& Naiker, V. (2006). Institutional ownership and corporate value. Managerial Finance. https://doi.org/10.1108/03074350610646753

Putranto, P. (2018). EFFECT OF MANAGERIAL OWNERSHIP AND PROFITABILITY ON FIRM VALUE ( Empirical Study on Food and Beverage Industrial Sector Company 2012 to 2015 ), 10(25), 96-104.

Robin, \& Amran, N. A. (2016). The effect of board of commissioners on family firms performance in Indonesia. Advanced Science Letters, 22(12), 4142-4145. https://doi.org/10.1166/asl.2016.8083

Salem, W. F., Metawe, S. A., Youssef, A. A., \& Mohamed, M. B. (2019). Boards of Directors' Characteristics and Firm Value: A Comparative Study between Egypt and USA. OALib, 06(04), 1-33. https://doi.org/10.4236/oalib.1105323

Susanti, L., \& Nidar, S. R. (2016). Corporate Board And Firm Value: Perspective Two-Tier Board System In Indonesia. Corporate Board And Firm Value: Perspective Two-Tier Board System In Indonesia, 5(5), 300-305.

Titova, Y. (2016). Are board characteristics relevant for banking efficiency ? Evidence from the US, 16(4), 655-679. https://doi.org/10.1108/CG-09-2015-0124

Tui, S., Nurnajamuddin, M., Sufri, M., \& Nirwana, A. (2017). Determinants of Profitability and Firm Value: Evidence from Indonesian Banks. IRA-International Journal of Management \& Social Sciences (ISSN 2455-2267), 7(1), 84. https://doi.org/10.21013/jmss.v7.n1.p10 
Vintilă, G., \& Gherghina, C. (2015). International Journal of Economics and Financial Issues Does Ownership Structure Influence Firm Value? An Empirical Research towards the Bucharest Stock Exchange Listed Companies. International Journal of Economics and Financial Issues I, 5(2), 501-514. Retrieved from http:www.econjournals.com

Widarjono, A., Anto, M. B. H., \& Fakhrunnas, F. (2020). Financing Risk in Indonesian Islamic Rural Banks : Do Financing Products Matter ? The Journal of Asian Finance, Economics and Business, 7(9), 305-314. https://doi.org/10.13106/jafeb.2020.vol7.no9.305

Yacob, S., Jambi, U., Rahayu, S., \& Jakarta, U. N. (2019). THE EFFECT OF BOARD OF DIRECTOR , BOARD OF COMMISSIONER AND AUDIT COMMITTEE ON VALUE OF FIRM TO ISLAMIC SOCIAL REPORTING AS A THE EFFECT OF BOARD OF DIRECTOR , BOARD OF COMMISSIONER AND AUDIT COMMITTEE ON VALUE OF FIRM TO ISLAMIC SOCIAL, (September). https://doi.org/10.22437/jb.v2i2.7214

Yameen, M., Farhan, N. H., \& Tabash, M. I. (2019). The impact of corporate governance practices on firm's performance: An empirical evidence from Indian tourism sector. Journal of International Studies, 12(1), 208-228. https://doi.org/10.14254/2071$8330.2019 / 12-1 / 14$ 